\title{
IMPROVING STUDENTS' WRITING SKILL THROUGH GRAPHIC ORGANIZER IN PROCESS WRITING
}

\author{
Zakky Yavani \\ zakky@syekhnurjati.ac.id \\ IAIN Syekh Nurjati Cirebon
}

\begin{abstract}
Within a production of text like written text, a writer in fact conducts series of processes which are not simple and easy. Grammar, vocabulary and content are among the problems; however, problems actually occur begin from even deciding what to write and how the ideas should be arranged. Employing collaborative classroom action research (CAR) design in two cycles, three meetings of 100 minutes each, this study aims to improve the students' writing skill using graphic organizer. 16 students of an English course in Malang, east Java participated in this study. To get the result, questionnaire, observation checklist, writing test and field notes are collected. Meanwhile, expected criteria of success were that all students achieved the minimum passing grade of 65 , and $85 \%$ of them actively involved in the implementation of the graphic organizer strategy and perceive the implementation positively. The finding shows the implementation of graphic organizer strategy was successful to improve the students' writing ability. All the students achieved the score at least 67 and $90 \%$ of them actively involved in the process of writing persuasive text, and positive perception existed.
\end{abstract}

Key words: writing skill, graphic organizer, process writing, persuasive text

\section{BACKGROUND}

In learning a language there are four macro skills namely listening, reading and writing. Within communication context, people usually get across their ideas in form of spoken or written text. However, unlike spoken language that tends to be more spontaneous, writing is more complex requiring to have more concise planning. It's not merely about linguistic features or language components such as grammar, vocabulary and mechanics but it's complexity also on moving from concepts, thought and ideas to written text Galbraith (2009:20). A writer must really understand what they are going to write and consider on the readability of the text one's has made to avoid miss interpretation toward the message being conveyed. Hence, for most students writing is complex and difficult to master and acquire especially for EFL learners (Brown : 2007,p.391; Nik et al: 2010, p.54; Cahyono and Widiati,2011,p.69). Eventually, these could possibly lead the students to have less enthusiasm in writing. In addition, Tanatkun $(2008$, p.8) claims that teaching writing skills to non-native students is challenging due to its slow improvement.

However, teaching EFL students how to write well is absolutely important, Raimes (1983) in Parila Santi et.al (2014) clarify three reasons why teaching students to write is necessary. First, writing reinforces the grammatical structure, idiom, and vocabulary that the teacher has discussed with the class. Besides, a chance to be adventurous with the language exists during the writing process and the students have more chance to become 
more involved in the language with themselves and the readers which eventually benefits their performance.

Considering the explanation above, the same phenomenon exists in Elementary level 4 (adult learners) of LBPP LIA, a class where access was available for researcher. Based on the preliminary research conducted using questionnaire and students' progress report in the class (a course place) in Malang. Some information related to students' problems in writing, mainly persuasive text, were found. First, the score of each aspects accumulation of content, organization, grammar, vocabulary and mechanics from the obtained data was unsatisfactory. It turns out that 13 students $(81 \%)$ of 16 students' persuasive text products did not reach the minimum passing grade (65) determined by the institution (LBPP LIA Malang). Hence, the improvement is necessary and it calls to find out a strategy that could possibly improve students' persuasive text writing performance. Below are the graphic describing students writing score aspects.

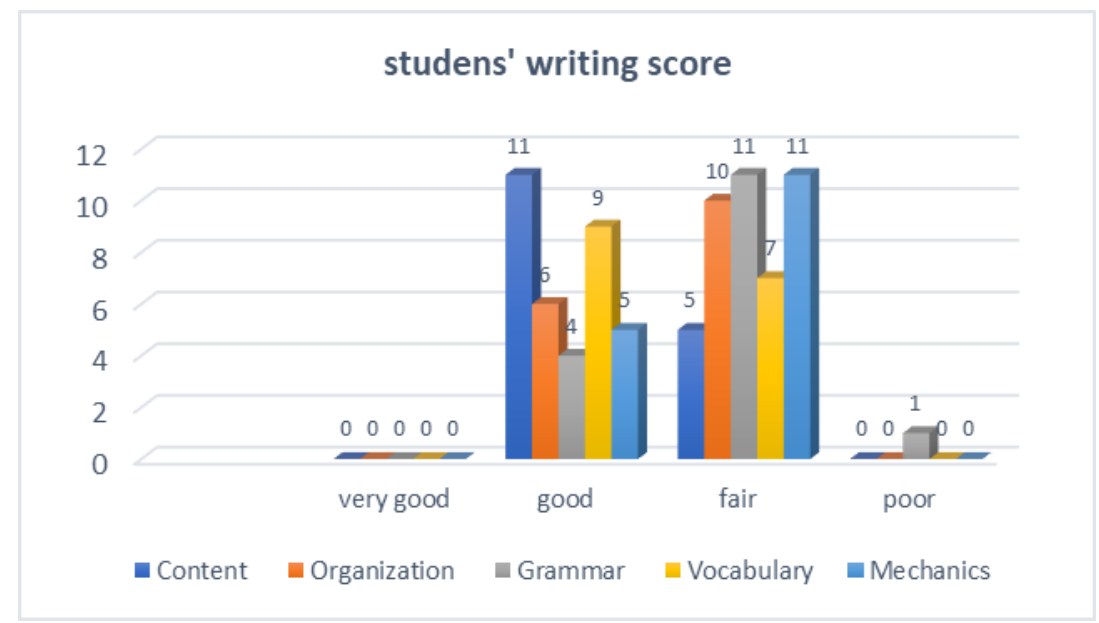

Graphic 1 Students' Writing Score From Preliminary Research

Second, from the questionnaire given to the students, it was found that students

Persuasive text is one of the text that is required to be mastered by students specifically perceive the following as problematic; 1) developing and arranging ideas, the questionnaire revealed that $56 \%$ of the students answered that it was difficult; 2) in choosing and developing vocabulary $50 \%$ of students think it was difficult; 3) $40 \%$ of the students admitted that they found difficulties in applying grammar rule used in writing the persuasive text; 4) Apparently, students did not do any stages in writing the article which show their incapability of using a strategy within the writing process. $50 \%$ of students confessed not to use any stage in writing the persuasive text.

Considering above data, it was believed that students' writing ability in persuasive article need to be improved. At the same time, a strategy need to be introduced to students in order to make the writing process easier and clearer which possibly benefits them later in the future.

\section{Persuasive Text}

In this study, the elaboration of persuasive text is taken from Kemper and Meyer (2009,p.220) below is the detail of persuasive text features description patterning the text based on two distinctive identification within a certain text; due to generic structure and the language features of the text. 


\begin{tabular}{|c|c|c|}
\hline No & Generic Structure & $\begin{array}{l}\text { Language } \\
\text { Features }\end{array}$ \\
\hline 1 & $\begin{array}{l}\text { Introductory statement } \\
\text { - It gives the author's point of view or } \\
\text { opinion and preview the argument that will } \\
\text { follow }\end{array}$ & $\begin{array}{l}\text { - Simple } \\
\text { present } \\
\text { - Modality } \\
\text { (can, may, } \\
\text { must, etc) }\end{array}$ \\
\hline 2 & $\begin{array}{l}\text { Details } \\
\text { - Give reason to support opinion } \\
\text { - It is to convince the audience } \\
\text { - The fact is given by providing the example } \\
\text { - Each idea is begun with transitional signal } \\
\text { - Emotive words are used to persuade readers }\end{array}$ & $\begin{array}{l}\text { - Transitional } \\
\text { marker (first, } \\
\text { then, finally } \\
\text { etc) and } \\
\text { cause/ effect } \\
\text { (because, so, } \\
\text { hence, etc) }\end{array}$ \\
\hline 3 & $\begin{array}{l}\text { Conclusion } \\
\text { - It sums up the argument and reinforces the } \\
\text { writer's point of view } \\
\text { - Make a call to an action using persuasive } \\
\text { sentences }\end{array}$ & \\
\hline
\end{tabular}

\section{Graphic Organizer}

From the observation and preliminary study result, the use of graphic organizer and seeing writing as a process considered to be appropriate strategy to solve the problem due to some reasonings; first, using graphic organizer in writing process could conceivably help the writer to see and differentiate fact from opinion, organization and vocabulary choice clearly and thoroughly facilitating recalling and retention (Shaffer.K, 2007) ; second, it helps writers easily see their thought making them easy to see what to improve, add or omit to create a best text and to perform it much better (Fry, 1981; Bromly et al,1995; Katayama et al, 2000); third, for adult learners graphic organizer facilitates or bridge what learners have already known with what they are learning. While writing means to display ideas in our head, it actually triggers long term memory and promote synthesis with new information (Maternal,2007, as cited in Mcknight, 2010,p. 2).

The implementation of graphic organizer in some research finding conducted both in native as well as learning English as foreign language yields positive results and recommended strategy to be applied mainly for reading and writing, although the implementation to other skills is widely possible. In native setting Barnett (2007) found that significant improvement to almost all of students over 3-weeks period when graphic organizer was used in reading and writing. Meanwhile, (Katayama et al, 2000; Donahoo, 2009) conclude that graphic organizer allows students to organize information and allow students to see their thinking; it computationally more efficient than outlines or text, engaging students in learning which resulted in encoding benefits.

in EFL setting, graphic organizer has been already applied. A study conducted by Mulyaningsih (2010) proved that its implementation influence students' writing performance; in terms of content, organization, vocabulary, coherence and cohesiveness. Additionally, it helps students as a note guide in presenting their writing in front of the class. Moreover, its implementation also possibly improve teaching and learning to be 
clearer and more communicative that can rise students' motivation (Noviansari, 2012; Andi. J et al, 2013).

\section{Process Writing}

Writing was seen as a product where the process was not necessarily important which made students feel less enthusiastic and possibly turning them to have negative perception toward writing activity. In this study, writing is considered as a series of process in which ideas are generated, put in first draft, organized and arranged in a whole, revised and corrected and finally writing a final draft. However, the process of writing, in fact, is not linear, but rather recursive. This means that writer plan, draft and edit but then often replan, re-draft and re-edit Harmer (2007, p.326). Seeing as a process concerned with the research showing that writing as process gives more benefits to future performance in writing activity Brown (2001, p. 335) added that the process approach is advantageous to students in learning language.

\section{METHOD}

This study was conducted at LBPP LIA (an English Course) Malang , 16 students (10 males and 6 females) from Elementary level 4 (English for adult) class participated in this research This study was conducted to find a better strategy as well as to improve students' writing skill based on the problem found in a classroom. The use of action research was decided since it suited the need mentioned designing systematic procedure by teacher to improve the practice of education Creswell (2012). In conducting this study teacher researcher (researcher become teacher who implement the strategy) worked collaboratively with his colleague in the process of observing, collecting and analyzing the data. Therefore, this study could be called as collaborative classroom action research (CAR). Proposed by Kemmis and Mc.Taggart (1988) cited in Latief, (2015, p. 149) the action research consists of four steps; Planning the action, Acting or implementing the instructional scenario, Observing or collecting data indicating the success of strategy in solving the classroom problem, and Reflection or analyzing the data to determine how far the data collected have shown the success of the strategy in solving the problem.

The data of the research came from the observation checklist, field notes, questionnaire and students' persuasive article score. Those data were gathered to be analyzed in determining the success of Graphic Organizer implementation in process writing to improve writing skill of persuasive article. In determining students' writing score, another rater was involved to compare the result. Meanwhile, analytical scoring rubric adapted from Jacob at al (1981) in Weigle (2002) was used; the aspects to assess are as follows: content (28\%), organization (20\%), Vocabulary (16\%), language use $(20 \%)$ and mechanic $(16 \%)$ which is described below.

\begin{tabular}{llll}
\hline Components & Score & Level & Criteria \\
\hline Content 28\% & $\mathbf{2 2 - 2 8}$ & $\begin{array}{l}\text { Very } \\
\text { good }\end{array}$ & $\begin{array}{l}\text { Knowledge, substantive, through development of } \\
\text { thesis, relevant to assigned topic and writer's } \\
\text { voice is confident and completely convincing. }\end{array}$ \\
\cline { 2 - 4 } & $\mathbf{1 5 - 2 1}$ & Good & $\begin{array}{l}\text { Some knowledge of the subject, adequate range, } \\
\text { limited development of thesis, mostly relevant to } \\
\text { topic but lacks detail. The writer's voice is } \\
\text { confident and help persuade the reader. }\end{array}$ \\
\cline { 2 - 4 } & $\mathbf{8 - 1 4}$ & Fair & $\begin{array}{l}\text { Limited knowledge of subject, little substance, } \\
\text { time inadequate development of topic. The } \\
\text { writer's voice needs to be more confident and }\end{array}$ \\
\hline
\end{tabular}




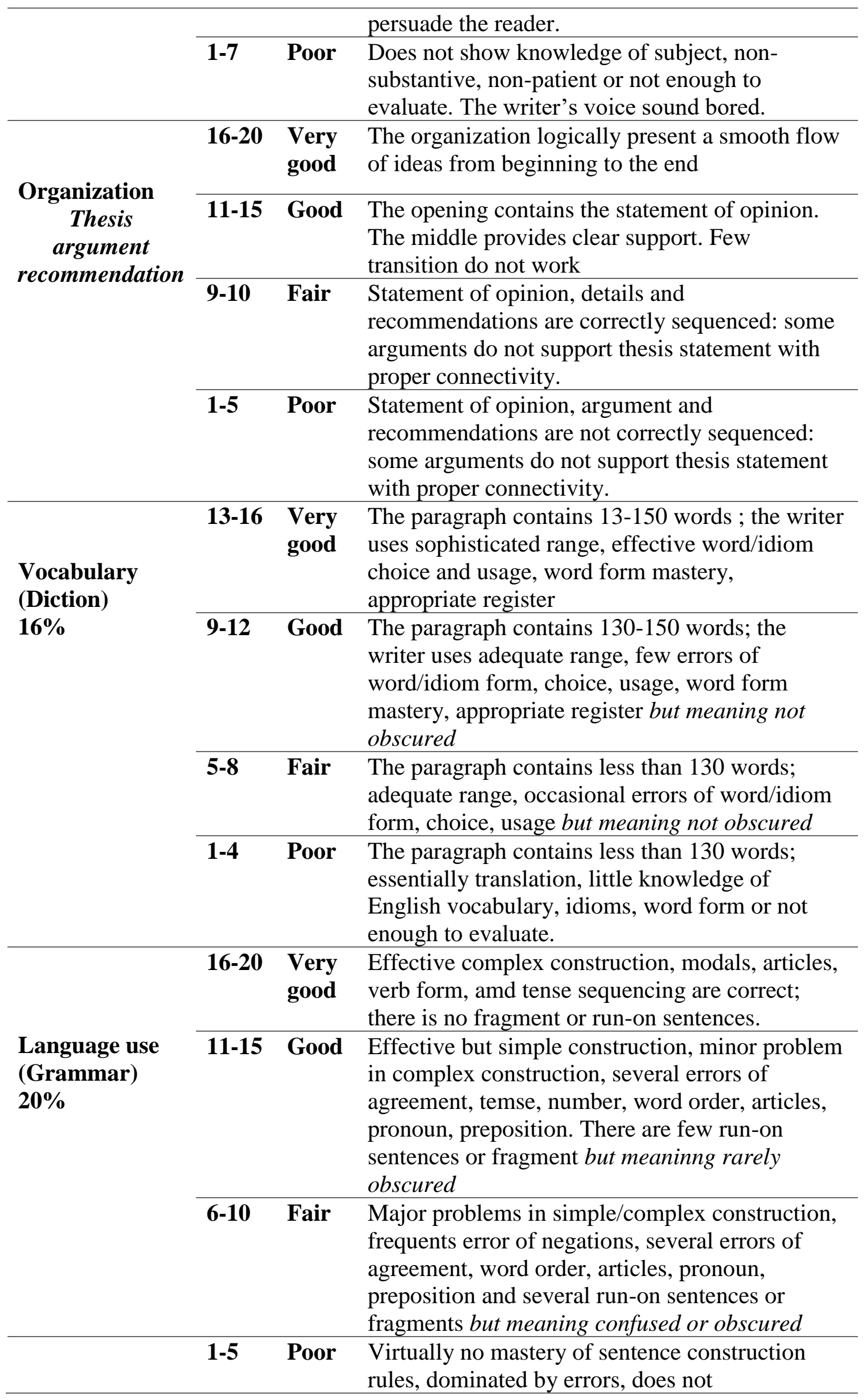




\begin{tabular}{|c|c|c|c|}
\hline & & & communicate, not enough to evaluate. \\
\hline \multirow{4}{*}{$\begin{array}{l}\text { Mechanic } \\
\text { Punctuation } \\
\text { Capitalization } \\
\text { Spelling } 16 \%\end{array}$} & 13-16 & $\begin{array}{l}\text { Very } \\
\text { good }\end{array}$ & $\begin{array}{l}\text { Demonstrate mastery of conventions: few errors } \\
\text { of spelling, punctuation, capitalization, and } \\
\text { paragraphing }\end{array}$ \\
\hline & $9-12$ & Good & $\begin{array}{l}\text { Occasional errors of spelling, punctuation, } \\
\text { capitalization, fragment but meaning not } \\
\text { obscured }\end{array}$ \\
\hline & $5-8$ & Fair & $\begin{array}{l}\text { Frequents errors of spelling, punctuation, } \\
\text { capitalization, poor hand writing, meaning } \\
\text { confused or obscured }\end{array}$ \\
\hline & $1-4$ & Poor & $\begin{array}{l}\text { No mastery of conventions, dominated by errors } \\
\text { of spelling, punctuation, capitalization, } \\
\text { handwriting illegible or not enough to evaluate. }\end{array}$ \\
\hline Score & \multicolumn{3}{|c|}{$\begin{array}{l}\text { Content + Organization + Vocabulary + Language use + } \\
\text { Mechanic }\end{array}$} \\
\hline
\end{tabular}

Table 2 Analytical Scoring Rubric Jacob at al (1981) in Weigle (2002)

\section{FINDING}

Within reflection stage of CAR procedure, it was found that from the data gathered during implementation of GO in cycle 1, it showed that $57 \%$ of students had already passed the minimum score of 65 and student's active involvement was $83 \%$. Moreover, from the data gained from students' response toward graphic organizer implementation conclude that the average score of students' positive perception was only $74 \%$ which means fair. It could be concluded that the result of the students' final draft did not meet the criteria of success. Therefore, it was necessary to conduct the next cycle.

In accordance to the students' improvement in the next cycle, some revision is made on the lesson plan (the sequence of lesson planning use three phase pattern; presentation, practice and produce). In presentation stage, teacher showed the slide and review the material by checking students understanding using question related persuasive article; then, teacher focused on the language feature mainly fragments and run on sentences by identifying sample sentences provided. Furthermore, some students' persuasive article organization, specifically in concluding sentence did not match to the detail or the explained or the title made. Considering this, modification in graphic organizer was necessary. It is, somehow, confused some students in organizing ideas when writing.

Likewise, in practice stage, the modification was on the media use. Instead of using video to show the product they have to write, using picture made students easily saw the features and the product completely and thoroughly. Besides, a corrections and feedback in editing process was given by the teacher because when students edited their friends 'work they missed some points while some others made wrong editing. This resulted in difficulties and create more confusion rather than providing solution.

In cycle two, involving two raters for scoring the students' writing had shown some improvements. its improvement satisfactorily met the minimum requirement decided by the institution; that is 65. All sixteen students (100\%) had significantly improve their persuasive writing score ranging from sixty seven (67) to eighty eight (88) with average improvement score of 19.93. convincing the researcher to end the cycle. to depict clearer 
students persuasive article improvement, below is the further elaboration of each writing aspects that students had.

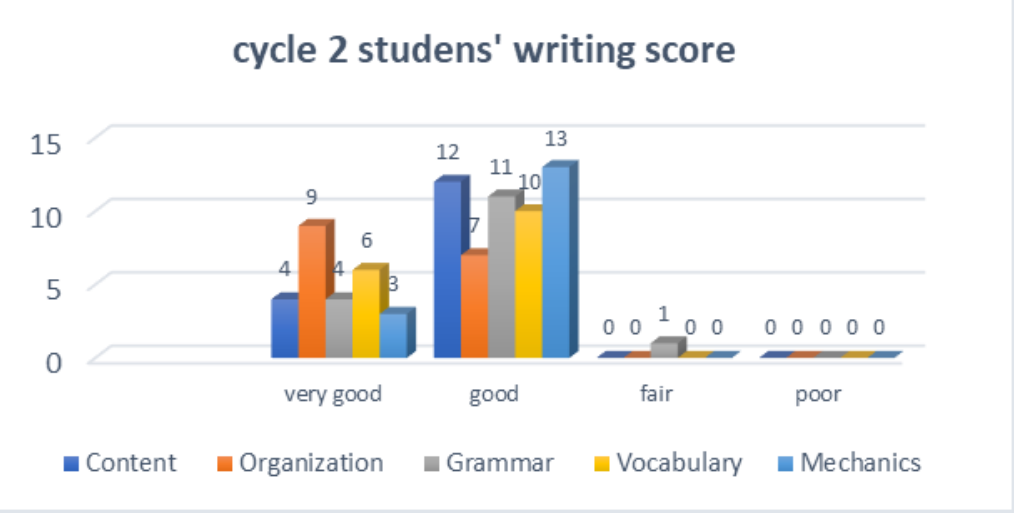

Graphic 2 Students' writing score in cycle 2

Furthermore, The teaching learning process indicates that the students were actively involved during the action. In meeting one and two ,87\% (14 students) were actively involved, and in meeting $90 \%$ (14 students) were involved. It means the average students' involvement was very good. The result of the questionnaire shows that the students gave good appreciation, got good learning experience, and got enthusiastic in doing the writing tasks. In the three meetings, generally they looked enthusiastic and happy participating in the process. The average percentage taken from questionnaire showed that students positive perception toward graphic organizer implementation in process writing (planning, drafting, editing and final version or publishing) was (85\%) which was categorized into good. Students' positive perception elaborations toward graphic organizer implementation in process writing are as follows: first, 56\% students agreed that graphic organizer could increase their vocabulary; second, $70 \%$ students agree that it helps them produced or expelled ideas; third, $100 \%$ students agree and strongly agree that it helped them arrange ideas and thought in writing persuasive article; fourth, $85 \%$ students agree that it could increase their motivation in writing persuasive paragraph. After reflecting and making revision, generally the suitable implementation of graphic organizer in writing process could be described as in the table below.

\begin{tabular}{clll}
\hline Teaching stage & Writing process & \multicolumn{1}{c}{ Activity } & Implementation \\
\hline \multirow{2}{*}{ Presentation } & & $\begin{array}{l}\text { Graphic organizer } \\
\text { introduction and } \\
\text { explanation }\end{array}$ & $\begin{array}{l}\text { Teacher } \\
\text { explanation } \\
\text { Class discussion }\end{array}$ \\
\hline \multirow{3}{*}{ Practice } & $\begin{array}{l}\text { Pre-writing/ } \\
\text { planning }\end{array}$ & $\begin{array}{l}\text { Generating ideas } \\
\text { using graphic } \\
\text { organizer }\end{array}$ & \\
\cline { 2 - 3 } & Drafting & $\begin{array}{l}\text { Writing a draft } \\
\text { using graphic } \\
\text { organizer as a blue } \\
\text { print }\end{array}$ & $\begin{array}{l}\text { Activity is } \\
\text { conducted in } \\
\text { pairs } \\
\text { collaboratively }\end{array}$ \\
\cline { 2 - 3 } & Editing & $\begin{array}{l}\text { Edit the draft made } \\
\text { then write }\end{array}$ & \\
\cline { 2 - 3 } & Writing final draft & $\begin{array}{l}\text { Making revision } \\
\text { then write to } \\
\text { publish }\end{array}$ & \\
\hline & & &
\end{tabular}




\begin{tabular}{llll}
\hline Produce & $\begin{array}{l}\text { Pre -writing } \\
\text { /planning }\end{array}$ & $\begin{array}{l}\text { Conduct the same } \\
\text { process above }\end{array}$ & $\begin{array}{l}\text { Activity is } \\
\text { conducted } \\
\text { Drafting }\end{array}$ \\
& & \\
Editing & Writing final draft & \\
\end{tabular}

Table 3 the implementation of graphic organizer frame work

\section{DISCUSSION}

Students' problems in writing persuasive article ensues in almost all aspect of writing like generating and developing idea, organizing idea correct grammar rules, using correct diction and develop vocabulary and the last was mechanic use. The result showed that by implementing graphic organizer in process writing students could solve the problems in writing persuasive article. This finding confirmed the similar result that it could improve students' writing skill (Shaffer.K,, (2007); Mulyaningsih, (2010); Antoni et al (2004).

Moreover, in terms of content students were assisted in generating ideas, visualize it and expand it. Either Mulyaningsih or Kusen (2011) agreed that visualizing the content helped students to plan better in writing. Additionally, applying process writing, students had a chance to rethink, add, omit when necessary. in organization, students can present and organize the information in concise ways that emphasized them to be aware of the relation between facts, ideas and concepts. Consequently, students were able to select and order the information to write based on a display made in graphic organizer. Also, graphic organizer facilitated students to have coherence in writing where they can easily the connection among ideas displayed by deciding the possible and best connector, transitional marker and rational arrangement. Thus, graphic organizer purposed explicit and implicit technique as also proposed by Martin and Othman (cited in Ulfiati, 2011: 135). Toward the vocabulary aspects, graphic organizer helped the students to select and to put the appropriate vocabulary. The strategy was strengthened by the recursive process of writing in which students get more chance to revise, edit and re-draft. Doing these several times students could possibly analyze and decide which is effective to be used in constructing their persuasive article.

In contrast, language use or grammar was not affected by the use of graphic organizer but the process writing did. In the process of editing particularly, student's discussion after drafting helped the students minimize the mistakes in language use (grammar). Muntasari (2012) found similar result showing that doing proof read or peer editing for revision could minimize their syntactical errors. Eventually, by having the process writing recursively, students had more chance to see their writing again and again before they made the final draft which could make them easily found if the sentences did not match or else had meaningfully incorrect. Hence, by multiple checking could also improve students persuasive text mechanics.

\section{Using Graphic Organizer in Process Writing}

During teaching and learning process in this study a shifting paradigm from writing as product to process proven to be beneficial to students' writing skill. The same result was also found by Maria (2010) and Muntasari (2012). Meanwhile, the success of Graphic Organization integration in writing process confirmed the positive result (Mulyaningsih, (2010); Barnett, (2007); Donahoo, (2009) and Advancement of research in Education, (2003)) . 
The activities could globally have divided into three; (1) presentation, where students lead background knowledge and model the sample; (2) practice, where students wrote persuasive article in pairs; (3) production, where students wrote persuasive article individually. During presentation stage, first, students were asked question which aimed to make students activate their background knowledge As Ur (1996) explained that it is to direct attention to the topic and stimulate thinking to probe deeply into issue. Students then were given a persuasive text sample and trained to use graphic organizer which made them engage in the creation of non-linguistic representation that stimulated and increased activity in their brain. Additionally, during the whole session of teaching and learning, students experienced the use of graphic organizer twice, first was writing in pairs in practice stage where students experience the use of graphic organizer with partner making students actively collaborate and encourage passive learner to be involved more. Second was experiencing the writing process individually in production stage.

Meanwhile, during writing process the use of graphic organizer begun from pre writing stage. Its success, in fact, lead to the success of drafting as well as the revising, editing and writing final draft. Cotton in Roberts (2004:8) in his research concluded students who engage in an array of prewriting experiences had greater writing achievement than those enjoined to 'get to work' without this kind of preparation. Drafting was the second stage of process writing where in this research the students put and arrange ideas in graphic organizer into draft. Graphic organizer played as a blue print that helped the students to write draft easily and take action where certain information need to omit, add or revise.

\section{Students' Involvement and Perception}

By applying graphic organizer in process writing, students were actively and eagerly involved in activity conducted, the result of observation during the last cycle was $90 \%$ which was categorized into very good. Here, the students were very actively involved during the writing process. In addition, similar result shows that students' perceptions are in line with their involvement. Students' percentage of positive perception toward the strategy was up to $85 \%$ or good indicating what they perceive are positive toward graphic organizer and process writing.

\section{CONCLUSION}

The finding of the research showed that first, the use of graphic organizer and the process writing in teaching and learning writing could solve the students' problem in writing persuasive article in terms of content, organization, language use (grammar) and the mechanic. Second, they were actively involved in the writing class activity and they also had positive perception toward the strategy implementation in writing lesson, particularly writing persuasive article. Furthermore, the finding proposed how graphic organizer in process writing should be executed; (1) Planning : generating ideas by asking students to write the important words and sentences into graphic organizer; (2) Drafting: asking the students to write the draft based on the words or sentences in graphic organizer; (3) Revising: distributing the peer editing sheet, asking students to be in pair and edit their friends' draft; (4) making final draft : asking students to make revision based on the feedback from their partners. However, these were recursive stages. 


\section{REFERENCECS}

Barnett, K.P. 2007. Graphic Organizer's Effectiveness in Teaching Comprehension in Reading and Social Students. Alabama. Accessed on September, 2012 from www. The University of Alabama.html.

Bromly.K, Irwin.D \& Modlo. 1995. Graphic organizer: visual strategies for active learning. New York: scholastic professional book.

Brown, H.D. 2001. Teaching by Principle: An Interactive Approach to Language Pedagogy $\left(2^{\text {nd }}\right.$ Ed). Wesley: Longman.

Cahyono and widiati. 2011. The Teaching of English As Foreign Language in Indonesia. Malang: state University of Malang press.

Creswell, J.W. 2012. Educational research: planning, conducting and evaluating quantitative and qualitative research. Boston: Pearson Education.

Donahoo, L. 2009. The Impact of Using Graphic Organizer on Written Language with Sixth Grade Resource Students. (online) retrieved from www.vcu,edu/cte/resources/newsletter_archive/TPO90607.pdf. Accessed on $2^{\text {nd }}$ December 2017.

Fry, E. 1981. What reading teachers can do to emphasize graphical literacy. Journal of reading $46(9): 48-51$

Galbraith \& David. 2009. Cognitive models of writing. GFL- journal (German as foreign language) no 2-3/2009.ISSN 1470-9570. (Online), www. gfl.journal.de/2-2009/ galbraith. Retrieved 14November 2014

Katayama, Andrew.D \& Robinsi. D.H. 2000. Getting Students 'Partially' Involved in Note-Taking Using Graphic Organizer. Journal of Experimental Education 68 (2) 115-119. Accessed on December $13^{\text {th }} 2017$.

Kusen.M. 2011. Using Graphic Organizer to Improve Students' Reading Comprehension. In Cahyono \& Mukminatin (Eds) Techniques and Strategies to Enhance English Language Learning (p 87-106). Malang: state University Malang press.

Kemper.D, Seranek.P \& Meyer.V. 2009. Write Source : A Book for Writing, Thinking and Learning. Massachusetts: great sources education group.

Latief, M.A.2014. Research Methods on Language learning An Introduction. Malang: State University of Malangpress.

Mulyaningsh .S. 2010. Using Graphic Organizer to Improve Students English Writing Skill in The Process of Communicating at The Fifth Grade Elementary School of Sekolah Citra Berkat Surabaya. Malang. the State University of Malang.

Muntasari.R. 2012. Using Process Genre Approach to Improve Students Writing Skill at English Department Stkip PGRI Blitar. Malang. the State University of Malang.

Mcknight, K.2010. The Teacher's Big Book of Graphic Organizer, Sanfrasisco: JosseyBass.

Noviansari, D. The Use of Graphic Organizer Method to Teach Narrative Text in Senior High School. Purworejo: Muhammadiyah University.

Nik.Y.A, Hamzah,A \& Rafidee. 2010. A comparative study on the factors affecting the writing performance among bachelor students. International Journal of Educational Research and Technology, 1(1): 54-59

Parila. S, Elis Ni Made., Suarnajaya, I wayan, Marhan \& Arsril.2014. The Effect of RAFT Strategy andAnxiety upon Writing Competency of the Seven Grade Students of SMP Negeri 3 MengwiInAcademicYear 2013/2014. Jurnal Penelitian UNDIKSHA, online, Volume 2 no 1(2014). 
Roberts, J.2004. 25 pre- Writing Graphic Organizer and Planning Sheets. New York: Scholastic.Inc.

Shaffer, K,2007. Graphic Organizers: Seeing is Believing. (online) http :www/Kathy's connection wordpress.com) retrieved on $3^{\text {rd }}$ December 2017.

Tanatkun T.P. 2008. Integrated Approaches to Improved Students Writing Skills for English Major Students. ABAC,Online,28(2):1,(Online).

Ur, P.1996. A Course In Language Teaching: Practical and Theory. Cambridge: Cambridge University press.

Ulfiati,L. (Ed). 2011 Explicit Techniques to Achieve Coherence in Essay Writing. Malang: state University of Malang press.

Weigl, S.C. (2002). Assessing Writing. Cambridge: Cambridge University press. 